\title{
Comprehensive Obesity Education for Family Medicine Residents
}

Birgit Khandalavala, MD | Jessica Koran-Scholl, PhD | Jenenne Geske, PhD

PRIMER. 2020;4:25.

Published: 9/25/2020 | DOI: 10.22454/PRiMER.2020.525629

\section{Abstract}

Background: Family medicine residents receive limited education on obesity management and obesity bias. Weight stigmatization is prevalent in primary care providers and trainees, and early mitigation is critical to optimize patient-centered care. Recent Provider Competencies for the Prevention and Management of Obesity include obesity bias. This report is intended to fill a current gap in obesity education for family medicine residents.

Methods: An interprofessional obesity teaching half day for family medicine residents incorporated the Provider Competencies and focused on five modules that addressed complexities of obesity and its clinical management. The obesity bias module focused on both explicit and implicit bias, assessment of implicit bias, preferential language usage, and mitigation strategies. An obesity-simulation empathy suit was available, and a public health expert described successful obesity care in a patient-centered medical home. Family medicine residents were surveyed prior to, immediately after the half-day of obesity teaching, and 15 months later.

Results: Survey results indicated $39.3 \%$ of residents had no previous biopsychosocial obesity education. Residents believed the content moderately $(68.8 \%)$ or mostly $(12.5 \%)$ impacted their approach to working with patients with obesity. Residents' comfort in working with patients with obesity as well as their perceived understanding of their own biases increased immediately after the intervention and was sustained 15 months later.

Conclusions: Our results suggest that a half day of obesity teaching can have a positive and sustained impact on family medicine residents. Additionally, this educational experience allowed for greater individual awareness building and insight regarding implicit bias. Such education for family medicine residents fills an identified gap in obesity education.

\section{Introduction}

One in four Americans are projected to have severe obesity within the next 10 years, particularly women, minorities, and lower socioeconomic cohorts. ${ }^{1}$ The majority of primary care residents, who will be at the forefront of the obesity epidemic, are reportedly deficient in knowledge and counseling skills in obesity. ${ }^{2-4}$ Limited obesity education in training contributes to this deficit. ${ }^{5.6}$ Weight bias, both explicit and implicit, is highly prevalent in most health workers, including family medicine physicians and trainees, and can have significant adverse impacts on health outcomes of patients with obesity. ${ }^{7,8}$ To optimize patient-centered health care, obesity education and reduction of weight stigmatization by primary care providers is critical. ${ }^{2-5,9,10}$

Leading national organizations including the American Academy of Family Physicians and the Society of Teachers 
of Family Medicine, recently released a seminal set of 10 core Provider Competencies for the Prevention and Management of Obesity. ${ }^{11}$ These competencies are grouped into categories that focus on (1) increasing knowledge about obesity, (2) strategies for incorporating interprofessional care for patients with obesity, and (3) ways to improve interactions with patients with obesity. ${ }^{11}$ Within the third category is a specific competency that addresses minimizing obesity bias. This competency includes exploring the personal understanding of weight bias and its impact on health and well-being, as well as the recognition and mitigation of weight biases in others. ${ }^{11}$

Published reports of obesity curricula that include obesity bias education in primary care graduate medical education are scarce. ${ }^{12,13} \mathrm{~A}$ few studies on obesity bias are reported for internal medicine residents ${ }^{14,15}$ and pediatric residents, ${ }^{16}$ but no reports specifically included family medicine residents. Education about the complex causes of obesity can reduce explicit bias, ${ }^{13,17,18}$ while techniques that mitigate implicit bias include personal implicit bias awareness assessment, empathy-building exercises, and adopting respectful language. ${ }^{12}$ Having identified a significant gap in the current obesity education of family medicine residents, and based on requests from our residents, we developed an obesity education curriculum. We adopted a comprehensive approach to the management of the patient with obesity, from lifestyle interventions to medical and surgical management, incorporating Provider Competencies surrounding obesity, and obesity bias education. ${ }^{19}$ We sought to evaluate the effectiveness of this curriculum.

\section{Methods}

The residency program in this Midwestern health science center trains approximately 72 family medicine residents per year. Each class is comprised of four subinterns (fourth-year medical students who train alongside the first-year family medicine residents), along with eight Air Force, three traditional, one underserved, and seven to eight rural residents per year. All available residents are required to attend teaching day sessions. In most cases, a significant portion of the residents cannot attend due to rotation commitments, personal leave, or other extenuating circumstances. Of the 33 house officers (HO) who attended the half day of obesity teaching (18 HO-I, $7 \mathrm{HO}-\mathrm{II}, 6 \mathrm{HO}-$ III and two subinterns), 28 completed the survey. While attendance was mandatory, participation in the research portion was voluntary. The interprofessional curriculum presented by an obesity medicine specialist, a clinical psychologist, a pharmacist, and a public health professor, consisted of five modules and ended with a grand rounds presentation (Table 1). Each of the modules addressed several of the 10 Provider Competencies for the Prevention and Management of Obesity.

The first module provided an introduction to etiology of obesity and the basics of nutrition, macronutrients, diets, and dietary patterns. Information came from the Centers for Disease Control and Prevention's Overweight and Obesity web page and Krause's Food \& the Nutrition Care Process, 14 th Edition. ${ }^{20,21}$ The second module integrated interactive learning components to address both implicit and explicit obesity bias and its impact on health care. Participants completed the web-based Harvard Implicit Association Test (IAT) ${ }^{22}$ for weight bias to assess personal implicit bias. Explicit bias was assessed using a validated Feeling Thermometer. ${ }^{23}$ Presenters also discussed the use of preferential, patient-first language, along with mitigation strategies for obesity bias. Residents could volunteer to wear an obesity simulation empathy suit, which simulates the size of a 600-pound person. They were encouraged to move around their environment while wearing the suit and to complete everyday activities such as bending down, moving through doorways, and sitting in various types of chairs.

The third module addressed the complex etiology of obesity along with an overview of the clinical management of obesity. ${ }^{24}$ This session included the genetic and environmental causes of obesity and the limited role of personal choice with the intent of mitigating explicit bias. Review of the comprehensive management of obesity consisted of lifestyle, pharmacological, and surgical evidence-based guidelines. ${ }^{25,26}$

The fourth and fifth modules described the pharmacological and surgical interventions for obesity, their efficacy, and their limitations. ${ }^{27,28}$ The half day of obesity teaching concluded with a grand rounds discussing the implementation of obesity care in a patient-centered medical home, presented by the chair of the Health Promotions Department from the College of Public Health. 
We searched the literature for a validated survey for the evaluation of similar obesity modules. Of the sparse results generated, many were extensively long, did not include implicit or explicit bias, or were difficult to administer in a brief time. ${ }^{5,29}$ Therefore the researchers developed two questions to assess participants' comfort levels in caring for patients with obesity and their understanding of their own obesity biases. We administered these questions before and after the half day of obesity teaching, and 15 months later. Prior to the half day of obesity teaching, participants were asked about previous education on managing patients with obesity. We did not collect identifiers and results could not be matched across time. We analyzed surveys using SPSS v 24.0 software. The University of Nebraska Institutional Review Board approved the study as exempt from review.

\section{Results}

Prior to the half day of obesity teaching, $39.3 \%$ of the residents $(n=11)$ reported no previous biopsychosocial obesity education. Routine teaching-day evaluations indicated that the program was well received and comparable to other topics presented during the academic year. Comfort and bias understanding results from the presurvey $(n=28)$, immediate postsurvey $(n=16)$, and 15 -month follow-up survey $(n=16)$ are summarized in Table 2 . In order to maintain anonymity, identifiers were not collected, so surveys could not be matched across time points.

Between groups analyses of variance revealed that the level of comfort in working with patients with obesity improved significantly from baseline to both the immediate postassessment (Time 2 ) and the 15-month follow-up (Time 3; Table 2; $P<.001$ ). While comfort level increased from Time 2 to Time 3 , this increase was not statistically significant. Similarly, respondents' perceived understanding of their own biases improved significantly from baseline to both the immediate and 15-month follow-ups $(P=.002)$. Immediately after the workshop, the majority of respondents indicated that the educational content would moderately (68.8\%) or mostly (12.5\%) impact their approach to working with patients with obesity.

\section{Discussion}

This half day of obesity teaching, that included obesity bias impact and mitigation, is the first reported for family medicine residents to incorporate the recent Provider Competencies for the Prevention and Management of Obesity. With $39 \%$ of residents reporting no prior obesity education, we addressed a significant gap in our current curricula. Within the framework of a half day of obesity teaching, we introduced education about caring for patients with obesity and understanding explicit and implicit obesity bias.

Previous studies have shown that targeted interventions can address stereotyping and communication skills, ${ }^{18}$ and our survey results support these findings. Results of our study suggest that residents' personal understanding and awareness of their own biases, as well as their comfort level in working with patients with obesity, improved as a result of the education.

A strength of our study was the involvement of faculty from multiple professions, providing participants with several perspectives on obesity care. We addressed comprehensive care of the patient with obesity, including explicit and implicit bias considerations, which have not been described in other reports for resident education. Incorporation of the Provider Competencies will improve residents' readiness to understand and appreciate the complexities of obesity care and to begin to mitigate bias when working with patients with obesity. The use of an obesity simulation empathy suit was reflective of a patient-centered approach and encouraged audience engagement. ${ }^{29}$ In addition, we developed all instructional materials from web-based and readily available evidence-based resources, allowing for easy reproducibility.

Further steps could consist of incorporating a skills-based curriculum, simulating patient encounters, capturing clinical outcome measures, and developing other structured educational opportunities. Participant learning should be assessed. Activities could include role modeling and developing lessons focused on treating complex patients and building empathy. $9,17,31,32$ Not all family medicine programs have local resources available, but national organizations are producing educational material that could be used by faculty teachers to cover this deficit (Table 
1). Individual programs can develop curricula that reflect their specific needs. Our intervention was targeted to adult obesity and did not include children or adolescents; future education should include updated pediatric obesity guidelines.

The Provider Competencies can now guide comprehensive obesity education to reinforce and ensure the best care for patients with obesity. Our curriculum can serve as a template for the introduction and development of educational materials of this emerging topic into family medicine residency education.

\section{Tables and Figures}

Table 1: Modules Included in the Obesity Teaching Day

\begin{tabular}{|c|c|c|c|c|}
\hline Modules & Faculty & Content/Source & $\begin{array}{l}\text { Provider Competency for Prevention } \\
\text { and Management of Obesity }{ }^{11} \\
\text { Addressed (Competency \#) }\end{array}$ & Time \\
\hline $\begin{array}{l}\text { Introduction } \\
\& \text { nutrition } \\
\text { basics }\end{array}$ & $\begin{array}{l}\text { Obesity } \\
\text { medicine } \\
\text { specialist, } \\
\text { MD }\end{array}$ & $\begin{array}{l}\text { Centers for Disease Control: } \\
\text { Overweight and Obesity }{ }^{20} \text { https:// } \\
\text { www.cdc.gov/obesity/index.html } \\
\text { Krause's Food, Nutrition and Diet } \\
\text { Therapy text book }{ }^{21}\end{array}$ & $\begin{array}{l}\text { - Demonstrate a working knowledge and } \\
\text { epidemiology of obesity }(1,2) \\
\text { - Describe the disparate burden of obesity and } \\
\text { approaches to mitigate it (3) }\end{array}$ & $30 \mathrm{~min}$ \\
\hline Obesity bias & $\begin{array}{l}\text { Director of } \\
\text { behavioral } \\
\text { medicine, } \\
\text { PhD }\end{array}$ & $\begin{array}{l}\text { Harvard Implicit Bias assessment }{ }^{22} \\
\text { https://implicit.harvard.edu/implicit/ } \\
\text { Selectatest.html } \\
\text { Obesity empathy suit simulation }\end{array}$ & $\begin{array}{l}\text { - Strategies to minimize bias with } \\
\text { subcompetencies of the impact of weight } \\
\text { bias on health (6) } \\
\text { - Recognizing and mitigating own and others' } \\
\text { biases; use patient centered communication } \\
\text { when working with patients with obesity }(7)\end{array}$ & $45 \min$ \\
\hline $\begin{array}{l}\text { Overview } \\
\text { of obesity: } \\
\text { etiology and } \\
\text { management }\end{array}$ & $\begin{array}{l}\text { Obesity } \\
\text { medicine } \\
\text { specialist, } \\
\text { MD }\end{array}$ & $\begin{array}{l}\text { Guidelines from the American } \\
\text { Association of Clinical } \\
\text { Endocrinologists docrine }{ }^{24} \\
\text { https://www.aace.com/files/obesity/ } \\
\text { final-appendix.pdf } \\
\text { Obesity algorithm (fee required) } \\
\text { https://obesitymedicine.org/obesity- } \\
\text { algorithm/ } \\
\text { The Obesity Society (TOS) } 26 \\
\text { https://www.obesity.org/information- } \\
\text { for-patients/ }\end{array}$ & $\begin{array}{l}\text { - Implement a range of accommodations and } \\
\text { safety measures specific to people with } \\
\text { obesity (8) } \\
\text { - Utilize evidence-based care/services for people } \\
\text { with obesity and with comorbidities (9) and } \\
\text { with obesity comorbidities. (10) }\end{array}$ & $45 \mathrm{~min}$ \\
\hline $\begin{array}{l}\text { Obesity } \\
\text { pharmacology }\end{array}$ & $\begin{array}{l}\text { Pharmacist } \\
\text { family } \\
\text { medicine, } \\
\text { PharmD }\end{array}$ & $\begin{array}{l}\text { Pharmacological Management of } \\
\text { Obesity Guideline Resources }{ }^{27} \\
\text { https://mww.endocrine.org/ } \\
\text { clinical-practice-guidelines/ } \\
\text { pharmacological-management-of- } \\
\text { obesity }\end{array}$ & $\begin{array}{l}\text { - Describe benefits of working interprofessionally } \\
(4) \\
\text { - Utilized evidence-based care/ services for } \\
\text { people with obesity or at risk for obesity (9) }\end{array}$ & $45 \mathrm{~min}$ \\
\hline $\begin{array}{l}\text { Bariatric } \\
\text { surgery }\end{array}$ & $\begin{array}{l}\text { Bariatric } \\
\text { surgeon, } \\
\text { MD }\end{array}$ & $\begin{array}{l}\text { American Society of Metabolic } \\
\text { and Bariatric Surgery guidelines } \\
\text { https://asmbs.org/resources/ } \\
\underline{\text { bariatric-surgery-guidelines-and- }} \\
\underline{\text { recommendations }} \\
\end{array}$ & $\begin{array}{l}\text { - Describe benefits of working interprofessionally } \\
(4) \\
\text { - Utilize evidence-based care/services for people } \\
\text { with obesity and with comorbidities (9) and } \\
\text { obesity comorbidities (10) }\end{array}$ & $45 \mathrm{~min}$ \\
\hline $\begin{array}{l}\text { Grand } \\
\text { rounds: } \\
\text { integration } \\
\text { partnerships } \\
\text { for obesity } \\
\text { management } \\
\text { in primary } \\
\text { care }\end{array}$ & $\begin{array}{l}\text { Public } \\
\text { health } \\
\text { promotions } \\
\text { dept. chair, } \\
\text { PhD }\end{array}$ & $\begin{array}{l}\text { Objectives: } \\
\text { Understand the demographics of } \\
\text { obesity in America } \\
\text { Recognize obesity's effect on } \\
\text { public health } \\
\text { Be able to utilize tactics to combat } \\
\text { obesity }\end{array}$ & $\begin{array}{l}\text { - Apply the skills necessary for effective } \\
\text { interprofessional collaboration and } \\
\text { integration of clinical and community care for } \\
\text { obesity (5) }\end{array}$ & $60 \mathrm{~min}$ \\
\hline
\end{tabular}


Table 2: Level of Comfort When Working With Patients With Obesity

Before an Obesity Workshop Before and After the Intervention

\begin{tabular}{|c|c|c|c|c|}
\hline Survey Question & $\begin{array}{l}\text { Preintervention } \\
(\mathbf{N}=\mathbf{2 8})\end{array}$ & $\begin{array}{c}\text { Immediately } \\
\text { Postintervention } \\
(\mathrm{N}=16)\end{array}$ & $\begin{array}{l}15 \text { Months } \\
\text { Postintervention } \\
\text { (N=16) }\end{array}$ & $\begin{array}{l}\text { Omnibus } \\
P \text { Value }\end{array}$ \\
\hline $\begin{array}{l}\text { How comfortable do you feel } \\
\text { working with patients with } \\
\text { obesity? } \\
\text { Mean (SD) }\end{array}$ & $2.77(.66)$ & $3.34(.47)$ & $3.50(.63)$ & $<.001$ \\
\hline $\begin{array}{l}\text { How well do you think you } \\
\text { understand your biases in working } \\
\text { with patients with obesity? } \\
\text { Mean (SD) }\end{array}$ & $2.48(.83)$ & $3.19(.66)$ & $3.13(.50)$ & .002 \\
\hline
\end{tabular}

a Scale: $1=$ not at all, 2=slightly, 3=moderately, 4=mostly

\section{Corresponding Author}

Birgit Khandalavala, MD

University of Nebraska Medical Center, Department of Family Medicine, 983075 Nebraska Medical Center, Omaha, NE 68198-3075. 402-559-3864. Fax: 402-559-6051

birgit.khandalavala@unmc.edu

\section{Author Affiliations}

Birgit Khandalavala, MD - Department of Family Medicine, University of Nebraska Medical Center, Omaha, NE Jessica Koran-Scholl, PhD - Department of Family Medicine, University of Nebraska Medical Center, Omaha, NE Jenenne Geske, PhD - Department of Family Medicine, University of Nebraska Medical Center, Omaha, NE

\section{References}

1. Ward ZJ, Bleich SN, Cradock AL, et al. Projected US state-level prevalence of adult obesity and severe obesity. N Engl J Med. 2019;381(25):2440-2450. doi:10.1056/NEJMsa1909301

2. Stanford FC, Johnson ED, Claridy MD, Earle RL, Kaplan LM. The role of obesity training in medical school and residency on bariatric surgery knowledge in primary care physicians. International journal of family medicine. 2015;2015. doi:10.1155/2015/841249

3. Guo JL, Gottlieb NH, Smith MM, Huang PP, Huang CM. Nutrition and physical activity counseling practices of family practice residents. J Cancer Educ. 2002;17(3):128-137.

4. Wadden TA, Volger S, Tsai AG, et al; POWER-UP Research Group. Managing obesity in primary care practice: an overview with perspective from the POWER-UP study. Int J Obes. 2013;37(S1)(suppl 1):S3-S11. doi:10.1038/ijo.2013.90

5. Acosta A, Azzalin A, Emmons CJ, Shuster JJ, Jay M, Lo MC. Improving residents' clinical approach to obesity: impact of a multidisciplinary didactic curriculum. Postgrad Med J. 2014;90(1069):630-637. doi:10.1136/postgradmedj-2014-132821

6. Colbert JA, Jangi S. Training physicians to manage obesity-back to the drawing board. N Engl J Med. 2013;369(15):1389-1391. doi:10.1056/NEJMp1306460

7. Puhl RM, Heuer CA. The stigma of obesity: a review and update. Obesity (Silver Spring). 2009;17(5):941-964. doi:10.1038/oby.2008.636

8. Khandalavala BN, Rojanala A, Geske JA, Koran-Scholl JB, Guck TP. Obesity bias in primary care providers. Fam Med. 2014;46(7):532-535.

9. Phelan SM, Puhl RM, Burke SE, et al. The mixed impact of medical school on medical students' implicit and explicit weight bias. Med Educ. 2015;49(10):983-992. doi:10.1111/medu.12770

10. FitzGerald C, Hurst S. Implicit bias in healthcare professionals: a systematic review. BMC Med Ethics. 2017;18(1):19. doi:10.1186/s12910-017-0179-8 
11. Bradley DW, Dietz W. Provider competencies for the prevention and management of obesity. The Robert Woodson Foundation [Washington, D.C. Bipartisan Policy Center, June 2017.]. 2017;1(1):1-12.

12. Puhl RM, Phelan SM, Nadglowski J, Kyle TK. Overcoming weight bias in the management of patients with diabetes and obesity. Clin Diabetes. 2016;34(1):44-50. doi:10.2337/diaclin.34.1.44

13. Puhl RM, Luedicke J, Grilo CM. Obesity bias in training: attitudes, beliefs, and observations among advanced trainees in professional health disciplines. Obesity (Silver Spring). 2014;22(4):1008-1015. doi:10.1002/oby.20637

14. Kushner RF, McGaghie WC, Pendarvis L. Medical residency training in the management of obesity. Acad Med. 2000;75(5):550. doi:10.1097/00001888-200005000-00080

15. Herzog J, Cameron K, Badaracco M, Kushner R. Development and implementation of a new OSCE for assessing resident competency in weight loss counseling. MedEdPublish. 2018;7(1):7. doi:10.15694/mep.2018.0000015.1

16. Rincon-Subtirelu M. Education as a tool to modify anti-obesity bias among Pediatric residents. Int J Med Educ. 2017;8:77-78. doi:10.5116/ijme.58b1.46e3

17. Kushner RF, Zeiss DM, Feinglass JM, Yelen M. An obesity educational intervention for medical students addressing weight bias and communication skills using standardized patients. BMC Med Educ.

2014;14(1):53. doi:10.1186/1472-6920-14-53

18. Poustchi Y, Saks NS, Piasecki AK, Hahn KA, Ferrante JM. Brief intervention effective in reducing weight bias in medical students. Fam Med. 2013;45(5):345-348.

19. Garvey WT, Mechanick JI, Brett EM, et al. American association of clinical endocrinologists and american college of endocrinology clinical practice guidelines for comprehensive medical care of patients with obesityexecutive summary. Endocr Pract. 2016.

20. Centers for Disease Control and Prevention. Overweight \& Obesity. https://www.cdc.gov/obesity/index.html. Published June 30, 2020. Accessed July 30, 2020.

21. Mahan LK, Raymond J. Krause's Food, \& the Nutrition Care Process. $14^{\text {th }}$ Edition. Saunders Philadelphia: Saunders; 2016.

22. Project implicit. https://implicit.harvard.edu/implicit/index.jsp. Accessed April 7, 2020.

23. Alwin DF. Feeling thermometers versus 7-point scales: which are better? Sociol Methods Res. 1997;25(3):318-340. doi:10.1177/0049124197025003003

24. Garvey WT, Mechanick JI, Brett EM, et al; Reviewers of the AACE/ACE Obesity Clinical Practice Guidelines. American association of clinical endocrinologists and american college of endocrinology comprehensive clinical practice guidelines for medical care of patients with obesity. Endocr Pract. 2016;22(s3)(suppl 3):1-203. doi:10.4158/EP161365.GL

25. The Obesity Society. Additional resources for obesity management. https://obesitymedicine.org/clinicianresources/obesity-medicine-resources-clinicians/. Updated 2020. Accessed March 11, 2020.

26. Obesity Medicine Association. Information for Healthcare Providers and Patients. https://www.obesity.org /information-for-patients/. Published March 23, 2020. Accessed July 30, 2020.

27. Apovian CM, Aronne LJ, Bessesen DH, McDonnell ME, Murad MH, Pagotto U, Ryan DH, Still CD. Pharmacological Management of Obesity Guideline Resources. Endocrine Society. https://www.endocrine.org /clinical-practice-guidelines/pharmacological-management-of-obesity. Accessed July 30, 2020.

28. American Society for Metabolic and Bariatric Surgery. Bariatric Surgery Guidelines and Recommendations. https://asmbs.org/resources/bariatric-surgery-guidelines-and-recommendations. Published December 30, 2014. Accessed July 30, 2020

29. Kushner RF, Zeiss DM, Feinglass JM, Yelen M. An obesity educational intervention for medical students addressing weight bias and communication skills using standardized patients. BMC Med Educ. 2014;14(1):53. doi:10.1186/1472-6920-14-53

30. Sukhera J, Watling C. A framework for integrating implicit bias recognition into health professions education. Acad Med. 2018;93(1):35-40. doi:10.1097/ACM.0000000000001819

31. Schwartz MB, Chambliss HO, Brownell KD, Blair SN, Billington C. Weight bias among health professionals specializing in obesity. Obes Res. 2003;11(9):1033-1039. doi:10.1038/oby.2003.142 
32. Gayer GG, Weiss J, Clearfield M. Fundamentals for an osteopathic obesity designed study: the effects of education on osteopathic medical students' attitudes regarding obesity. J Am Osteopath Assoc.

2017;117(8):495-502. doi:10.7556/jaoa.2017.099

Copyright $\odot 2020$ by the Society of Teachers of Family Medicine 